Journal of Southeast Asian

\title{
Four Poems: Snakehead Fish; Departures; Capitol; and Preparations for Southeast Asia
}

Bryan Thao Worra

Lao Assistance Center, thaoworra@aol.com

Follow this and additional works at: https://docs.lib.purdue.edu/jsaaea

Part of the Anthropology Commons, Asian American Studies Commons, and the Critical and Cultural Studies Commons

\section{Recommended Citation}

Worra, Bryan Thao (2007) "Four Poems: Snakehead Fish; Departures; Capitol; and Preparations for Southeast Asia," Journal of Southeast Asian American Education and Advancement: Vol. 2 : Iss. 1, Article 8.

DOI: $10.7771 / 2153-8999.1090$

Available at: https://docs.lib.purdue.edu/jsaaea/vol2/iss1/8

This document has been made available through Purdue e-Pubs, a service of the Purdue University Libraries. Please contact epubs@purdue.edu for additional information.

This is an Open Access journal. This means that it uses a funding model that does not charge readers or their institutions for access. Readers may freely read, download, copy, distribute, print, search, or link to the full texts of articles. This journal is covered under the CC BY-NC-ND license. 


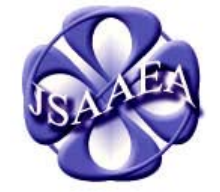

Volume 2

\section{Journal of Southeast Asian American}

Education \& Advancement

WWw.JSAAEA.org
A peer-reviewed

scholarly journal

published by the

National Association

for the Education \&

Advancement of

Cambodian, Laotian, and Vietnamese Americans (NAFEA)

\section{Four Poems: Snakehead Fish; Departures; Capitol; and Preparations for Southeast Asian \\ by \\ Bryan Thao-Worra}

\section{Snakehead Fish}

When the water's wrong

You just pick up your things,

Suck in a last breath for the old times

And walk all the way to a new pond

So clean you can smell it.

When everything is all right:

You gobble your neighbors up

One at a time like a thresher in frenzy

With a gorged wide-mouth grin,

Blimping up till you're long

As a line of five dollar bills.

When we get around to it, Your passports will be revoked:

Pisces non grata a la America.

We'll have to go back to Asia

To eat you.

On the news they say you're

A tasty reincarnated sinner

And I wonder how karma works out

Like that, making a funny fish face

For my visiting niece

over a bowl of sour soup.

\footnotetext{
@)

SORERIGHISRESERVEDReaders are free to copy, display, and distribute this article, as long as the work is attributed to the author(s) and the Journal of Southeast Asian American Education \& Advancement, it is distributed for non-commercial purposes only, and no alteration or transformation is made in the work. More details of this Creative Commons license are available at http://creativecommons.org/licenses/by-ncnd/2.5/. All other uses must be approved by the author(s) or JSAAEA.
} 


\section{Departures}

The monks gave us a bag of Thai oranges

Before we left for the States.

Next time we come, we'll have learned more Lao,

We promise.

They promise there will be more to show us the next time.

Sitting outside the Khop Jai Deu

Waiting for our bus to come

Elvis is crooning "Return to Sender"

Because there's no such number,

And no such home.

I took a photo of the fountain

Next to the Scandinavian Bakery,

Tuk-tuk drivers loitering nearby.

Handing them some fruit,

They ask, "How long are you staying in Laos?"

And I reply,

"This is our last day."

The sun looks like it could be peeled wide open

While I take a bite of a giant orange,

Trying to wring out a last memory from this light,

Wondering when the King's song is ever going to end

The scent of citrus on my hand

Sinks deeply past my bones,

Trying to harden into an anchor

The shape of a kind heart. 


\section{Capital}

Vientiane is a memory.

I want to use the word buried,

locked inside my mind

so tight I barely get

any visitation hours.

But Vientiane is

more than a memory.

She's alive

and so am I.

She's just going on with her life, shaking her head at

my foolish Romanticism-

a stale baguette

trying to paint her

when she was a waif.

While she sends me

a hundred worn photographs

of her golden spires and muddy feet, I admit, I've barely written back,

left to wonder who she's really become

and would have been,

had I been there the way

I always think I wanted to.

As if this would make any difference

worth mentioning in the mornings

of the children born with no memories of me. 


\section{Preparations For Southeast Asia}

There were children whose curt sense of geography

Calculated our destination just south of Pluto.

Enough turmoil from enigmas. Time for answers.

Queries to dispel our conjurations of rumor and smoke.

At least we could say "we went," "we returned,"

"We did not stay forever."

Our hummock of a travel agent

On a corner of University Avenue

Smiled like a hunter's moon:

“You don't need lots of money where you're going. Just a little, and you'll be living like kings.”

I wanted to utter some vaporous remark

About the life expectancy of Asian royalty,

But simply took my passport and tickets

Marveling at our modern keys of paper and numeral, Opening doors that might not have been locked as tightly As we once believed,

Packing to send our peripatetic hearts hurtling through the atmosphere Some 600 miles per hour, bent on finding a home

Our parents alone would recognize. 


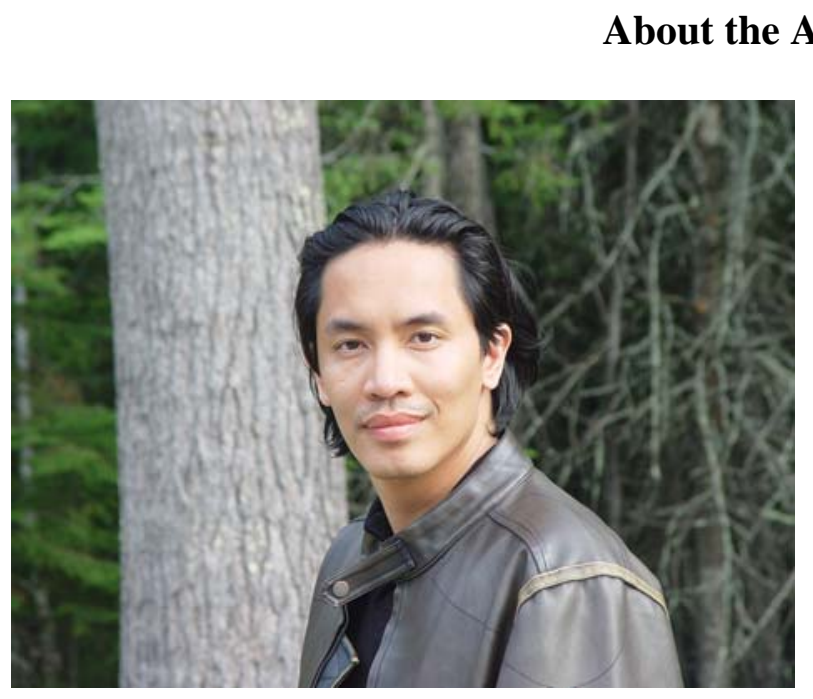

Bryan Thao Worra is the Laotian American author of On The Other Side Of The Eye, Touching Detonations, and The Tuk-Tuk Diaries: My Dinner With Cluster Bombs. He also volunteers as the literary editor for Tripmastermonkey.com, Bakka Magazine and AsianAmericanPoetry.Com. You can learn more about his work by visiting www.myspace.com/thaoworra or writing him at thaoworra@aol.com 


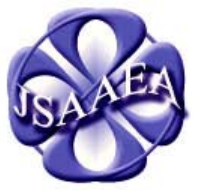

Volume 2

\section{Journal of Southeast Asian American Education \& Advancement WWW.JSAAEA.org}

\section{Editor}

Dr. Wayne E. Wright

University of Texas, San Antonio

Associate Editors

Dr. Chhany Sak-Humphry

University of Hawaii

Dr. KimOanh Nguyen-Lam

California State University, Long Beach

Book Review Editor

Dr. Leslie Turpin

School for International Training

\section{Creative Works Editor}

Phouang Hamilton

Washington Office of Superintendent of Public Instruction

\section{Special Advisor}

Anne Frank

University of California, Irvine, Southeast Asian Archives

\section{Editorial Assistant}

Shereen Bhalla

University of Texas, San Antonio
A peer-reviewed scholarly journal published by the National Association for the Education \& Advancement of Cambodian, Laotian, and Vietnamese Americans (NAFEA)

\section{Comments and questions for the editorial staff may be directed to jsaaea@lists.sis.utsa.edu}

\section{Editorial Review Board}

Dr. Carl L. Bankston III

Tulane University

Dr. Pollie Bith-Melander

San Jose State University

Dr. Phala Chea

Lowell Public Schools

Dr. George Chigas

University of Massachusetts, Lowell

Dr. Changming Duan

University of Missouri, Kansas City
Dr. Sophal Ear

Syracuse University

Dr. Nancy H. Hornberger

University of Pennsylvania

Dr. Samlong Inthaly

Minneapolis Public Schools

Dr. Peter Nien-Chu Kiang

University of Massachusetts, Boston 


\author{
Dr. Kevin K. Kumashiro \\ University of Illinois, Chicago \\ Dr. Stacey Lee \\ University of Wisconsin, Madison \\ Dr. David Chanpannha Ley \\ Montgomery County Public Schools \\ Dr. Sue Needham \\ California State University, Dominguez Hills \\ Dr. Bic Ngo \\ University of Wisconsin-Madison \\ Dr. Max Niedzwiecki \\ Rights Working Group \\ Dr. Leakhena Nou \\ California State University, Long Beach \\ Dr. Clara Park \\ California State University, Northridge \\ Dr. Mark Pfeifer \\ Texas A\&M University, Corpus Christi \\ Dr. Loan T. Phan \\ University of New Hampshire \\ Dr. Bounlieng Phommasouvanh \\ Minnesota Department of Education
}

\author{
Dr. Karen Quintiliani \\ California State University, Long Beach \\ Dr. Kalyani Rai \\ University of Wisconsin, Milwaukee \\ Dr. Fay Shin \\ California State University, Long Beach \\ Dr. Nancy J. Smith-Hefner \\ Boston University \\ Dr. Yer J. Thao \\ Portland State University \\ Dr. Myluong Tran \\ San Diego State University \\ Dr. Khatharya Um \\ University of California, Berkeley \\ Dr. Linda Trinh Vo \\ University of California, Irvine \\ Dr. Terrence G. Wiley \\ Arizona State University \\ Dr. Zha Blong Xiong \\ University of Minnesota \\ Dr. Kou Yang \\ California State University, Stanislaus
}

\section{Doctoral Student \\ Editorial Review Board}

\author{
Keo Chea \\ University of Pennsylvania \\ Vichet Chhuon \\ University of California, Santa Barbara \\ Loan Dao \\ University of California, Berkeley \\ Annie BichLoan Duong \\ San Joaquin County Office of Education \\ Ha Lam \\ Arizona State University \\ Ravy Lao \\ University of California, Santa Barbara \\ Vanna Som \\ Harvard University
}

Rassamichanh Souryasack

University of California, Santa Barbara

$$
\begin{gathered}
\text { Giang Tang } \\
\text { University of Minnesota }
\end{gathered}
$$

Layheng Ting

State University of New York, Albany

Loan Tran

University of California, Santa Barbara

Phitsamay Sychitkokhong Uy

Harvard University

Yang Sao Xiong

University of California, Los Angeles 